LETTER

\section{Acute toxic \\ leukoencephalopathy in migrant workers exposed to organic solvents in construction materials}

Organic solvents are widely used in the construction industry. Migrant workers, an important source of construction workers in China, are at risk of solvent intoxication. Here we describe two young male migrant workers who were diagnosed with acute toxic leukoencephalopathy due to intense exposure to organic solvents contained in construction materials.

Patient 1 had been applying tape to pipes in non-ventilated, underground apartments for 5 days before he developed a slow reaction time, headache, nausea and vomiting. He worked $10 \mathrm{~h}$ per day with a 10 -min break in both the morning and the afternoon. The adhesive tape he used produced a strong smell, and he did not wear any personal protective equipment. Patient 2 had been painting internal walls for 6 days before he developed headache, nausea, vomiting, diplopia and intermittent drowsiness. He worked in confined spaces for up to $8 \mathrm{~h}$ at a time without any protective equipment. He complained of irritated eyes and throat caused by the strong fumes from the liquid lacquer he used.

Brain MRI of patient 1 showed subcortical and periventricular white matter lesions (figure 1A) plus involvement of bilateral cerebellar dentate nuclei (figure 1B), while patient 2 showed diffuse symmetric white matter lesions in subcortical and periventricular areas and internal capsules (see online supplementary figure S1). Toluene was detected in the adhesive tape patient 1 worked with, and toxicology screening showed benzoic acid in his blood and urine $(0.2 \mu \mathrm{g} / \mathrm{ml}$ and $0.5 \mu \mathrm{g} / \mathrm{ml}$, respectively; undetectable in the general population). A blood sample from patient 2 was positive for 1,2,3-trichloropropane (TCP) $(7.6 \mathrm{ng} / \mathrm{ml}$; undetectable in the general population). Thus, diagnoses of acute toxic leukoencephalopathy induced by toluene and TCP were established in the two workers. Following intensive treatment and care, both patients recovered well enough to resume normal life within 6 months.

Toluene and TCP are organic solvents commonly used in the manufacture of paints, adhesives and many other materials. $^{1}{ }^{1}$ Well known acute organic solvent-induced central nervous system neurotoxicity includes depression and narcosis, while long-term adverse effects include neurodegeneration. ${ }^{3}$ Kornfeld and his colleagues have speculated that leukoencephalopathy induced by chronic exposure to organic solvents causes a demyelination process similar to that see in adrenoleukodystrophy. ${ }^{4}$ However, acute toxic leukoencephalopathy due to organic solvents has not been reported previously. The clinical picture and reversible course of the condition in our patients were similar to those of acute toxic leukoencephalopathy induced by other causes such as chemotherapy and heroin inhalation. ${ }^{5}$

Our patients had worked in confined spaces without proper ventilation for a short period of time. Neither the quantity of toxic substances in the materials they used nor the concentration of solvent vapour in their work environment were monitored. As neither wore protective equipment, it is highly likely that they absorbed solvents through inhalation and skin contact.
The two cases described here highlight the necessity of improving practice hygiene and environmental surveillance for migrant workers in order to prevent solvent intoxication. ${ }^{1}$ Clinicians should be aware of acute solvent-induced leukoencephalopathy so that appropriate examination and treatment can be provided in a timely manner.

Taomian Mi, ${ }^{1}$ Chongyu Han, ${ }^{2}$ Yuan Wang, ${ }^{1}$ Hongmei $\mathrm{Ma}^{2}{ }^{2}$ Jianping Jia, ${ }^{1}$ Yuchuan Ding, ${ }^{3}$ Fatema Esmail, ${ }^{3}$ Jun Chen, ${ }^{2}$ Lihua Peng, ${ }^{2}$ Jia $\mathrm{Xu}^{2}{ }^{2}$ Yong-Xin Sun ${ }^{1}$

'Department of Neurology, Xuan Wu Hospital, Capital Medical University, Beijing, China

${ }^{2}$ Department of Neurology, You Anmen Hospital,

Beijing, China

${ }^{3}$ Department of Neurological Surgery, Wayne State University School of Medicine, Detroit, Michigan, USA

Correspondence to Yong-Xin Sun, No. 45 Changchun Street, Xi Cheng District, Beijing, 100053, China; sisisun@sina.com

Contributors All authors contributed to the planning conduction and reporting of the work described in this article. YS identified and managed the patients, while $\mathrm{CH}$ and TM wrote the article. YS is responsible for the overall content as guarantor. TM and $\mathrm{CH}$ contributed equally to the article and should be considered joint first authors.

Funding This study was supported by the Beijing outstanding talents cultivation fund (No. 2012D005018000007). The National Natural Science Foundation of China, 30600656; The New-Star plan of Science and Technology of Beijing, Beijing Committee of science and technology, 2004B12.

Competing interest None.

Provenance and peer review Not commissioned; internally peer reviewed.

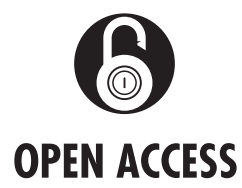

Open Access This is an Open Access article distributed in accordance with the Creative Commons Attribution Non Commercial (CC BY-NC 3.0) license, which permits others to distribute, remix, adapt, build upon this work
Figure 1 T-2 weighted MRI images showing subcortical and periventricular white matter lesions (A) with involvement of bilateral symmetric dentate nuclei (B).

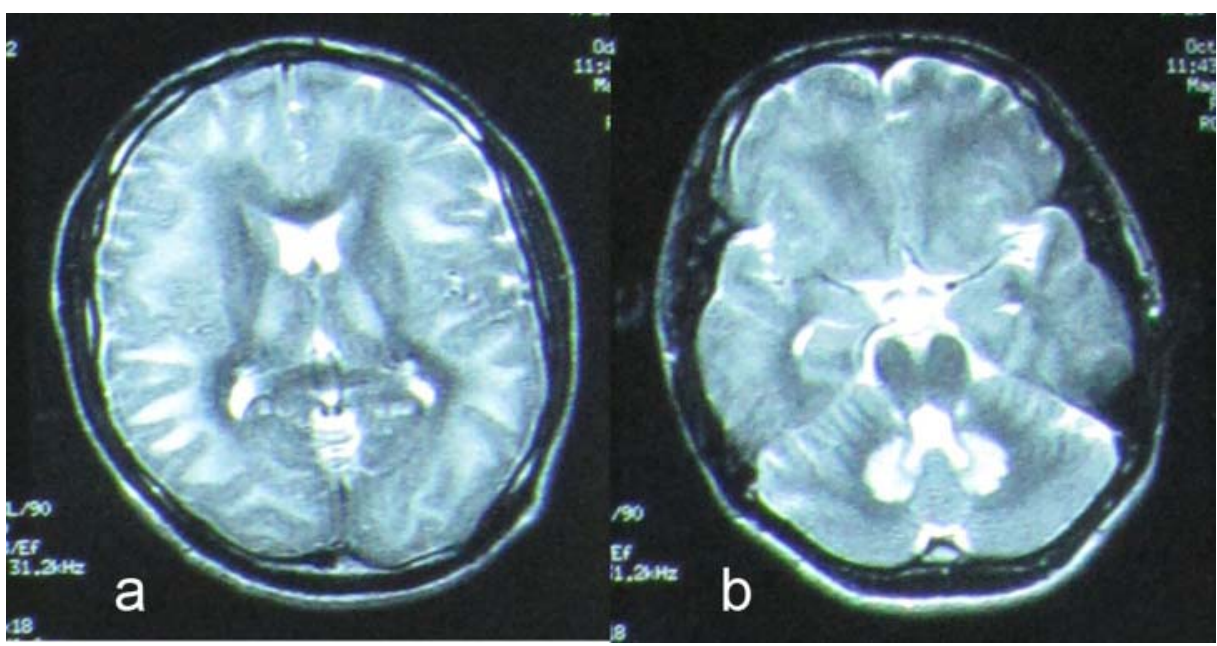


non-commercially, and license their derivative works on different terms, provided the original work is properly cited and the use is non-commercial. See: http:// creativecommons.org/licenses/by-nc/3.0/

- Additional material is published online only. To view please visit the journal online (http://dx.doi.org/10. 1136/oemed-2012-101302).

To cite Mi T, Han C, Wang $Y$, et al. Occup Environ Med 2013;70:435-436.

Received 2 December 2012

Revised 21 December 2012

Accepted 28 December 2012

Published Online First 6 February 2013
Occup Environ Med 2013:70:435-436.

doi:10.1136/oemed-2012-101302

\section{REFERENCES}

1 Estevan C, Ferri F, Sogorb MA, et al. Characterization and evolution of exposure to volatile organic compounds in the Spanish shoemaking industry over a 5-year period. J Occup Environ Hyg 2012;9:653-62.

2 Tafazoli M, Kirsch-Volders M. In vitro mutagenicity and genotoxicity study of 1,2-dichloroethylene, 1,1,2-trichloroethane, 1,3-dichloropropane, 1,2,3-trichloropropane and 1,1,3-trichloropropene, using the micronucleus test and the alkaline single cell gel electrophoresis technique (comet assay) in human lymphocytes. Mutat Res 1996:371:185-202.

3 Dick FD. Solvent neurotoxicity. Occup Environ Med 2006:63:221-6, 179

4 Kornfeld M, Moser AB, Moser HW, et al. Solvent vapor abuse leukoencephalopathy. Comparison to adrenoleukodystrophy. I Neuropathol Exp Neurol 1994;53:389-98.

5 McKinney AM, Kieffer SA, Paylor RT, et al. Acute toxic leukoencephalopathy: potential for reversibility clinically and on MRI with diffusion-weighted and FLAIR imaging. AJR Am J Roentgenol 2009;193:192-206 